\title{
Popular or Partial Sovereignity?
}

\section{Xhabir Zejnuni}

Ph.D. candidate at the EUT

\section{Doi:10.5901/ajis.2014.v3n6p163}

\begin{abstract}
Nowadays sovereignty is one of the fundamental concepts in all jurisdictions and bends in all its forms. In theory it is talked too much about sovereignty, no matter where it derives from and how it is conducted. But, in practice things change, because it is not performed correctly what is noted in general in all modern constitutions. Questions do not lack in this respect as: where sovereignty derives from; to whom sovereignty belongs; what are the limitations of sovereignty; what are the problems that arise when there is a conflict to respect the appointed head of sovereignty; by what means is done the transfer of sovereignty in case of need? Another problem has to do with the relationship between the direct and indirect sovereignty and its manner of implementation.
\end{abstract}

\section{Sovereignty and Its Meaning}

Sovereignty can be understood as the availability of the rights to make political, economic, and social choices for the community of reference and to impose and implement them.

Article 2 of the Albanian Constitution ${ }^{1}$ applies to par. 1 states that "The sovereignty of the Republic of Albania belongs to the people" and in par. 2 continues "The people exercise sovereignty through their representatives or directly".

Article 2 is of great importance, because when it disposes that "sovereignty belongs to the people", is intended to emphasize that sovereignty means that there is no one above the people, because although it is true that citizens choose their political representatives, these representatives should serve the interests of their constituents, like all ordinary civil servants and not their own interests. Furthermore, not only sovereignty belongs to the people, but our legal system is organized like all other modern legal systems in the triple division of powers ${ }^{2}$ which are fundamental safeguards to ensure that the Constitution and the sovereignty of the people be respected maximally. Thus, we have executive power that belongs to the government, the legislative power that belongs to Parliament and the judiciary power that belongs to the courts. This threefold division of power serves as a defense in the sense that if one of these three powers violates the constitution or the interests of the community, then the other two branches of government can intervene without any condition from interested parties. But the daily reality shows that facts change, because we observe that the Constitution is violated or not implemented as it is written, that the sovereignty and the separation of powers, the people can only dream about, that lack guarantees for the protection of individuals, etc. Today political parties whatever they are, are the owners of the State, as the ordinary citizens can exercise their free will during elections only expressing their consent to different political parties and everything it stops for these individuals where it starts, to repeat the same thing in subsequent polls. Thus questions arise such as: where is the sovereignty of the people; what does the judiciary power when it is completely violated the Constitution? These are questions that hardly we can provide the correct answers, because the reasons are well known.

According to Calamandrei "Our Constitution is partly a reality, but only partially is true. Partially it is still a program, an ideal, a hope, a commitment, a work to be done"3.

An example of how it is "respected" the sovereignty of the people is worth mentioning. In Italy in 2011 were collected 1.200.000 signatures for two referendums: one to repeal the current electoral law, which does not allow citizens

\footnotetext{
${ }^{1}$ Approved by the Law No. 8417 dated 21.10.1998.

${ }_{2}^{2}$ According to Montesquie: "Legislative power serves to make laws, the executive power serves to respect these laws and judicial power to sanction the offender of these laws".

3 Piero Calamandrei Florence, (21 Aprill 1889-Florence, 27September 1956) Discussion on the Constitution ', Milan, 26 January 1955

(Discorso sulla Costitucione, Milan, 26 gennario 1955). 
to identify the candidates for Parliament, but who decides that they should be appointed by the parties and the second for the repeal of changes introduced by law no. 270 dated 21.12.20054. Italy's Constitutional Court by a political and not a legal assessment of the facts, has stressed that these referendums should not be done, "declaring unacceptable

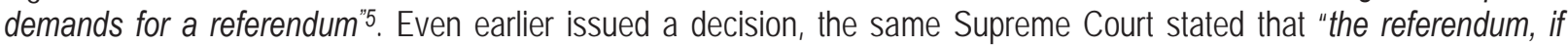
there would be a favorable outcome for repeal, will allow the lack of a constitutional law, which should be functional and self-enforcing, at any time in its entirety"6. In this way, the Constitutional Court instead of making responsible the citizens continues to ignore them.

The current Constitution of Albania (consisting of 183 articles) mentions "sovereignty of the people" only in section 2, in which you can note that it is joined with the principles that consider the State a entirety of aware citizens and not as an association of individuals who need to be guided and controlled by 140 MPs with immunity, regarding the fact that what should be done or not done.

Constitutional pompous declaration that "Sovereignty belongs to the people", not just in practice is enforced, but also overlooked, because the states which label themselves as "democratic£, through their constitutions although recognize as the titular "sovereignty" the people, in practice they remain "oligarchic". In all legal orders people exercise their sovereignty effectively only at the time of voting and at the same time is by voting "waive" his sovereignty by delivering it to its chosen, to whom believe exactly the power to decide "on behalf of his (people)". Therefore, it appears as a necessity to decide to whom belong the sovereignty, or who is the true holder of the decision-making power.

According to Giuseppe Grassi " "State, which is the depositary of the command's power , runs it through his law enforcement; but these bodies are put in motion and take authority and are shaped by the people who directly or indirectly gives to them all their power to maneuver".

Regarding the terms that should accompany sovereignty as "sovereignty lies in the people, belong to the people, derives from people, it is people's, etc." In our Constitution is set to "belong to the people" as" it derived from people "can create dilemma that if something was emerged by the people, does 'not return to the people.

But Albania's Socialist Constitution of $1976^{8}$ in Article 5, paragraph 1 stated that "All state power in the Popular Socialist Republic of Albania derives from the working class and belongs to it". It is known then how it stems and how power is exercised by the people in a communist country with a dictatorial ruling Party.

Even in Germany, article 20, par. 2 of the Basic Law9 provides that "All state power derives from the people. It is exercised by the people in elections and referendums and by specific authorities of the legislative, executive and judicial power". Even though the above two articles resemble little, their substantial differ much, given the different legal systems of these two countries.

Even the choice of the term "people" is not accidental, because it comes not only to voters, but to all those who are citizens, men, women, children, even for foreigners living in the territory of a country ${ }^{10}$. Even the fact that sovereignty belongs to the people should not be forgotten, because it is not the prime minister, ministers and MPs to govern, because they are the only representatives of the people, but must listen and implement the aspirations and wishes of the voters

If the Parliament has the power and the mandate to make laws and to decide on behalf of the people (representative democracy), then it can and should be done in accordance with the will of the people. But it is raised the question whether there is a form of manifestation of the will of the people, regardless of its elected representatives, namely the Parliament even though the instruments and acts of popular sovereignty is contemplated by the Constitution and cannot be ignored for any reason.

Court decisions are issued in the name of the people, because in fact justice should be applied only to interest and in the spirit of the entire community and not in favor of one or another party in the society. In line with the concept of democracy are indeed very principles that allow the emergence of popular will. These principles are set out in the articles. $48,81,134,150,151$ of the Constitution.

\footnotetext{
${ }^{4}$ The so-called Law Porcellum.

5 The Constitutional Court of Italy, Decision Nr. 13 dated 12.01.2012.

6 The Italian Constitutional Court, Decision Nr. 15 and16 of 2008.

7 Giuzepe Grasi was an Italian lawyer and politician (Manduria1883-Rome 1950.

${ }^{8}$ Approved with the Law Nr. 5506, dated 12/28/1976.

9 So called German Constitution of 1949 (Grundgesetz).

10 In terms of residents in all aspects but not transition as in the Netherlands, where Article 1 of its constitution stipulates that 'All persons who are in the Netherlands shall be treated equally in equal circumstances. Discrimination on the basis of religious belief, political opinion, race or sex or on any other bases will not be permitted.
} 
So article 48 states that "Whoever, alone or as a group, may address requests, complaints or comments to public bodies, which are required to respond to the terms and conditions established by law". While Article 81 continues to par. 1 that "Council of Ministers every deputy, and 20 thousand voters have the right to propose laws" and Article 134, par. 1 states that "The Constitutional Court is put into motion only at the request of: $g$ ) individuals". The Constitution also provides in Article 150, par. 1 even the referendum when the "nation, through 50 thousand citizens entitled to vote, have the right to a referendum to repeal the law, and to request the President of the Republic holding a referendum on issues of special importance" and in Article 151, par. 1 that "law approved by referendum is promulgated by the President of the Republic".

But the most effective tool that can allow people to directly exercise sovereignty is the petition ${ }^{11}$ and is actually very strange how our Constitution does not provide the petition as a formal request that is made by the people to his representatives. This fact cannot and should not be ignored, as it is a tool that allows individuals to exercise directly the sovereignty based on Article 2. To ignore the petition means to ignore the sovereignty of the people, resulting in the weakening or elimination the concept of representation. Thus, Parliament who ignores this right or demands made by the people, deprive him of the sovereign function instead of remain as representative of the sovereign people ${ }^{12}$. If only the parties, which are the same that make up Parliament can do what they want, then the possibility of using the sovereignty of the people is approaching zero thus leading to a usurpation of the sovereignty of the people by its representatives. What it is decided by the will of the people through constitutional provisions should not be denied later, because without a popular legal force parallel to the representatives, which has the task of control and rejection of the latter, there can be no improvements, but only deterioration which will compromise the entire legal system.

Article 2 of the Albanian Constitution has a double meaning: in par. 1 positive, which is probably the best known, and in par. 2 negative, that is forgotten and not without purpose.

It should be added that sovereignty initially is attributed and thus belongs to the people who do not take either as a gift or as a concession by someone, but is a natural attribute of the people themselves, with the result that no one has the power of revocation, removal or reduction of this sovereignty. Sovereignty of the people is exercised directly through referendum or indirectly through administrative and parliamentary elections. Legal systems based on popular sovereignty, usually are defined as democratic systems. For some of these constitutional specialists these terms have into account the way of representation and not its formal side.

French Constitution of 1958 says very clearly in Article 3 that "National sovereignty belongs to the people who exercise it through its representatives and by referendum".

A democratic republic is characterized by the participation of the people in the governance of the State, through the election of legislative power by all citizens. In this regard, through the Constitution has become effective the principle of popular sovereignty and is made a very clear choice, the one of the dominance of the form of "representative democracy" applicable to the polls by the voters, their representatives in Parliament and in local government.

The Constitution proclaims the sovereignty of the people, that the power of the people is expressed through the parliamentary elections, the powers of government, as well as through the judicial system. If elected MPs are attending other matters and are declared not involved in the task of transformation in local government sovereignty, putting themselves outside trinomial people- parliament-power, then they undermine the Constitution in its foundation and thus fight the sovereignty of the people from whom they are elected. In this case the politicians will not be punished, but will be punished and betrayed the citizens. The people exercise the sovereignty in two ways: through representative democracy, in which the electoral body, i.e. the active part of the people choose their representatives at least in Parliament, which in turn takes part in the appointment or designation of other bodies of Government and that of direct democracy, which is characterized with the direct participation of individuals in political elections. Some institutes of direct democracy and popular in our legal system and mentioned in the Constitution, mainly serve in complementary and corrective functions of representative model, where the most important is abrogating referendum. Sovereign comply with the entirety of subjects and each of them is accepted at the time of conclusion of the contract as "an inseparable part of the whole". In addition, the sovereign is not an external force, opposing entities, but are the subjects themselves equipped with contract are

11 Petition (from Latin Peto-seek to get) is a requirement for an authority-usually the government or public body. In spoken language a petition is a document signed by many people and was addressed to a public or private entity. Based on the scope, it is possible to classify the petitions as: proposing to invite the legislature to approve rates that fill a legislative gap (vacation); awareness when are intended to focus the interest of the recipient on a specific topic; repeal, if invite the legislator to abolish a special legal norms.

12 The Italian Constitution states in article 50 that 'All citizens may request petitions to rooms for legislative measures or to express collective needs. 
created as sovereign, thus creating a "public person".

Persons who have signed the contract may be set at the same time as citizens when mentioning the fact that each of them is irreplaceable part of a sovereign entity and as the subject given that each of them is subject of the law enacted by the will of overall that is precisely the will of the sovereign people.

Rousseau wrote on the Social Contract of1762-s that: "We are still relatively far from the revolution and its idea of popular sovereignty may seem still a theoretical concept away from any possibility of verification in practice"13.

\section{The limitations of Sovereignty}

Popular sovereignty could face some restrictions, as in the case that cannot be object to referendum: tax laws, human rights, taxes and so on.

In this regard, the Article 151, par. 2 of the Albanian Constitution states that "Issues related to the territorial integrity of the Republic of Albania, with the restriction of fundamental freedoms and human rights, with the budget, taxes and financial obligations of the state, with placement and removing of the state of emergency, with declaration of war and peace and with the amnesty cannot be submitted to a referendum".

In Italy Article 11 of its Constitution is the basis of participation in the international system of protection of human rights and states that "sovereignty may be limited in terms of equality with other states, to create an international order that ensures peace and justice among nations". In addition, Italy undertakes to promote international agreements and organizations that have this intention. Of particular importance are the Universal Declaration of Human Rights of December $10^{\text {th }}, 1948$ of the General Assembly of the UN, and the European Convention on Human Rights in1950. European Convention has a special feature, since it does not only contains a detailed list of rights, but dominates the participating states under the authority of "the European Court of Human rights", established in Strasbourg, where the European countries participating citizens may address to this Court, when are violated their fundamental rights.

\section{Democratic Aspects of Sovereignty}

"Democracy" (comes from the Greek word demos-people and cracy-strength, power) is a word with which all political regimes seek to brag. There is no political system that has not stated democratic in the past and today, as communist regimes, Arab countries regimes, dictatorships of African countries or generals or colonels of southern American, modern states today, etc. The use in different manners of democracy is made possible because the word "democracy" mean the power of the people, power to the people and power on behalf of the people. Democracy can be direct and representative. But we must not forget also that direct democracy is in an inferior position compared with representative democracy, because the first has its field action closer in time and space.

Democracy envisaged by the Constitution is a competitive democracy and includes a variety of conditions, such as:

- Free elections, the right to vote is guaranteed to all;

- Pluralism of political parties and the opportunity to create new parties;

- Protection of minorities from the power of the majority;

- Opportunity for the minority to become the majority;

- Freedom of thought and equal access to the political debate.

Another important aspect of Article 2 is the one that relates to the democratic nature of the State, where those elected by the people to govern should not be considered "owners" of the state, but his "servants". Thus, "the governed" should be considered "sovereign" to all intents and purposes, although this concept is depreciated over the years. But there is a prevailing opinion that states that there should be people to govern themselves, and another opinion according to which the people should be governed by their elected representatives. Individual task is to govern in the basic issues of their lives, and it is the duty of rulers to lead people in order for him to follow the right way, for the benefit of the entire community. Therefore, to create a single sovereignty, no matter if it is owned by the people or the government, is entirely without bases, because the sovereignty exercised by politicians is different from popular sovereignty. Many politicians are nothing more than "the cream" of the people, who have been fortunate enough to become someone within their social group. From this fact it follows that people need not to possess sovereignty, as it already has the tools to control

13 Jean-Jacques Rousseau, "The Social Contract", 2005, p. 35 ("Du contrat Social", 1762). 
politicians, to whom the people himself have given the opportunity to lead them. Today almost every constitution of the twentieth century as in France, in Germany and then in Spain after the fall of Franco, etc. reiterates the same principle that "sovereignty belongs to the people". Therefore the popular sovereignty is confirmed as one of the key concepts, essential and characteristic of constitutional democracies.

\section{Constitutional Problems Concerning Sovereignty}

Albania has been for several year part of some Treaties and with Albania's acceptance as a candidate member of the $\mathrm{EU}$, it is already part of a broader legal system of supranational nature, handing over a part of its sovereignty to these treaties to cases. But which part of its sovereignty? Albanian Constitution refers to "sovereignty" in Section 2, noting that "it belongs to the people", but on the other hand Article 5 states that "The Republic of Albania applies international law mandatory for it", allowing restrictions on sovereignty, necessary to ensure the functioning of an international legal system that ensures peace and justice in the world. It seems clear that Articles 2 and 5 refer in fact two different aspects of "sovereignty" of their classic concept: Article 2 refers to internal sovereignty, i.e. relations between the State and individuals that live in the territory of that State, and Article 5 refers to external sovereignty, i.e. the State's relations with other countries or international organizations. Article 5 of the Constitution does not limit the sovereignty of the people, but only the sovereignty of the State in relation to other countries and this is the fundamental dividing line between internal sovereignty and external one that should decide the relations with European Union. Should consider the fact that internal sovereignty is not just about the "principles" of the legal system, but with the basic power that characterizes the State in the relations with its citizens. Moreover, Article 123, par. 1 of the Constitution provides that "The Republic of Albania, on the basis of international agreements, delegates to the international organizations state powers to certain issues". In this case, sovereignty about individual issues passes to the international organizations, but also we consideration the opportunity as provides par. 3 of Article 123 as "the Assembly may decide that the ratification of such an agreement be made by referendum". Even in this case is Parliament that decides whether or not a referendum is going to be held and not the sovereign people.

\section{Adaptation of European Legal Systems of EU Right}

Adaptation to treaties happens in practice through "execution order", which is usually part of the law that authorize the ratification of treaties, and making the treaties to enter the domestic system by taking the rank of the source that gives them executive strength as common lows. In Albania international treaties, including those relating to the European Union should have the force of law and as such cannot be contrary the Constitution. In Albania, its Constitution in Article 116, par. 1, provides that "Normative acts that are effective in the entire territory of the Republic of Albania are: a) the Constitution; b) ratified international agreements; c) laws; d) Bylaws of the Council of Ministers "and continues to Article 122, par. 2 that "An international agreement ratified by law has supremacy over national laws that do not agree with". At the first rate, the international agreement is ranked with other legal resources, and in ongoing rate, it (international agreement) exceeds domestic rates in case of conflict with it. In France for example, it is expressly provided that "les traités ou accords régulièrement ratifiés ou approuvés ont, dès leur publication, une autorité supérieure à celle des lois"14.

In Germany, by contrast the ratification of the Lisbon Treaty has been achieved with the adoption of two constitutional laws, which were subject to control by the Constitutional Court, since this treaty was considered contrary to the German Basic Law, which states specifically that the participation of the Federal Republic of Germany aims "development of the European Union", besides the presence of a series of "anti limitations" in the implementation of community law whose foundation is the principle of democracy, which should always be respected. Compared with the mechanisms provided by countries such as France and Germany, Italy has two basic problems: on one hand, the absence of a constitutional provision expressed regarding relations with the European Union and on the other side the nature of customary law by which always is given implementation and execution to international treaties.

${ }^{14}$ French Constitution of 1958 Article 55. "Treaties or agreements ratified or approved shall be published by a higher authority than the laws". 


\section{Conclusion}

Representative democracy gives politicians time to implement their program within a specified timeframe. But then, these politicians with various reasons seek the extension of the deadline to implement their program. But the problems are not over yet, as there is not understood where sovereignty lies when it is delegated to be exercised by parliamentarians, who for many different reasons, but that are not related to the sovereign people are missing in Parliament to 6 months, but no further or a day ${ }^{15}$. Or what sovereignty could be in Italy when Berlusconi government was forced to step down to be replaced by the Monti Government, or if by internal party "coup d'état" Letta Government was replaced with Renzi Government? How decided the sovereign people in these two cases? It is quite simply, not decided at all, because in the people's place decided others. Or not yet is understood what kind of sovereignty it is about when although it is delegated to Kosovo parliamentarians in the last election, they have not yet succeeded in forming the Government. And the issues related to popular sovereignty have no end.

\section{References}

Italy's Constitutional Court, Decision no. 13, dated 12.01.2012.

Italy's Constitutional Court, Decision no. 15 and 16 of 2008.

Constitution of Albania, approved by Law no. 8417, dated 21.10.1998.

Socialist Constitution of Albania, approved by Law Nr.5506, dated 28/12/1976.

The French Constitution of 1958

The Italian Constitution of 1948

The German Basic Law of 1949 (Grundgesetz)

15 The Albanian Constitution. Article 71 par. 2. "MP mandate expires or is invalidated as appropriate: d) when is absent without any excuse in the Assembly for 6 months in a row". 